\title{
A comparative study of the lifelong learning propensities of English language learners: nationality, gender and length of study
}

\author{
Tanju Deveci \\ Petroleum Institute, UAE
}

\begin{abstract}
Acquiring a foreign language may be a lifelong endeavor, and this requires one to approach it from a lifelong learning perspective. However, learners may not always be ready for such an approach. It is important to know where learners stand in their orientations toward learning and consider this when planning educational activities. Therefore, it is necessary to determine language learners' readiness for lifelong learning (LLL) in order to support their language development. This paper reports the findings of a study conducted to identify the LLL propensities of some Turkish and Emirati university students learning English as a foreign language in their local contexts. The study included 61 Emirati and 47 Turkish students, with a mean age of 19. Data were collected using a research tool with three sections: Demographics, the Lifelong Learning Tendency Scale (LLLTS - developed by Coskun \& Demirel (2012)), and a survey with six open-ended questions. Student's t-test, the Kruskal-Wallis test and the MannWhitney U-test were used to compare the quantitative data in terms of the participants' nationalities, gender and length of study. The results showed that both Turkish and Emirati students had a moderate level of propensity for LLL. However, the Turkish students' overall LLLTS scores as well as certain subskills were found to be higher than those of the Emirati students. Gender was not found to make a significant difference in the students' LLL orientations, while motivation was found to be lower at a statistically significant level for those learning English for more than a year. Suggestions are offered for the development of language learners' LLL skills.
\end{abstract}

\section{Introduction}

The well-known English saying "You can't teach an old dog new tricks" appears to have equivalents in various languages including Arabic and Turkish, and suggests that learning becomes increasingly difficult or even impossible as we age. However, the phrase "from the cradle to the grave", which also appears to exist in these languages, challenges this belief and indicates that learning cannot be confined to a particular age. The fact that learning starts even before the cradle, as genes develop in the womb, has been well documented in published studies (Kolata, 1984; Hepper, 1989; Martens, 2013); therefore, it seems useful to consider opportunities for learning at all stages of life.

\section{Definitions of lifelong learning}

The idea that learning is a lifelong process is not new: evidence for this way of thinking can be found in Plato's Republic. However, this idea did not come to the forefront of modern education until the 1920's, when education philosophers including Dewey, Lindeman and Yeaxle offered a more systematic approach to learning throughout life by emphasizing the fact that learning is life itself, and therefore it needs to be seen as an intrinsic part of life (Ayhan, 2006). This encourages us to acknowledge the fact that learning can take place in informal, formal and non-formal settings throughout life. So, lifelong learning (LLL) can be defined as

a process of both deliberate and unintentional opportunities influencing learning throughout one's

life span. (Iqbal, 2009, p. 1).

Deveci, T. (2015). A comparative study of the lifelong learning propensities of English language learners: nationality, gender and length of study. Learning and Teaching in Higher Education: Gulf Perspectives, 12(1). 
Attempts to make a distinction between learning and education, and to define LLL, culminated in the adoption of one generally accepted definition of LLL by the UNESCO Institute of Education:

... education is not a once-for-all experience that is confined to an initial cycle of continuous education commenced in childhood, but a process that should continue throughout life. Life itself is a continuous learning process, but each person needs specific opportunities for continuing, purposive and sequential learning in order that he or she may keep abreast of technical and social change, may equip himself or herself for changes in his or her own circumstances... (Titmus, 1979, p. 29).

This definition of education gave other international institutions the impetus to further elaborate on the notion with an emphasis on learning rather than education. The Organization for Economic Co-operation and Development (OECD), for instance, defines the term as

a process of individual learning and development across the life-span, from cradle to grave - from learning in early childhood to learning in retirement. It is an inclusive concept that refers not only to education in formal settings, such as schools, universities and adult education institutions, but also to 'life-wide' learning in informal settings, at home, at work and in the wider community. (OECD, 1996)

\section{Language learning and lifelong learning}

Drawing attention to increased life expectancies and apparent changes in age structures, the Commission of the European Communities (1995) published a white paper on lifelong learning in 1995. As a result, new goals were set for member countries with a heavy focus on LLL. In terms of language learning, the White Paper set the objective of encouraging the citizens of member nations to learn at least three of the European languages to a level of proficiency. It was stated that this would provide individuals with both occupational and personal benefits by allowing them to work and travel abroad. Under an educational initiative called the SOCRATES programme, the European Commission encouraged the production of language teaching materials for young learners, with the belief that learning a foreign language should become one of the foundations of acquiring knowledge. The White Paper noted that an early introduction to learning a foreign language promotes proficiency in that language, and also raises awareness of one's own mother tongue. As a result, people may have more open minds, intellectual agility and expanded cultural horizons. The White Paper also noted that foreign language learning is particularly important in vocational training since it makes people more employable.

The increase of interest in lifelong learning led the UNESCO Institute of Education to change its name to the UNESCO Institute for Lifelong Learning (UIL) in 2006 in order to reflect the philosophy of learning continuing throughout the lifespan, whether in school, out of school or in other ways. Two of the Insititute's medium-term strategy documents (UNESCO Institute of Education, 2003; UNESCO Institute for Lifelong Learning, 2009) underline the importance of languages and language learning. The first strategy document emphasizes the role of languages in protecting cultural diversity. It is asserted that local languages reflect the identity of local communities and show young people their history and cultural individuality; therefore, teaching local languages acts as a bridge to teaching other languages. The second document, on the other hand, summarizes the challenges faced and emphasizes the benefits of lifelong learning at individual, societal and global levels. Regarding language learning, the strategy aims to promote bilingual education and local languages, with a particular attention to African languages.

Deveci, T. (2015). A comparative study of the lifelong learning propensities of English language learners: nationality, gender and length of study. Learning and Teaching in Higher Education: Gulf Perspectives, 12(1). 


\section{Lifelong learning skills}

Learning a foreign language is a lifelong effort: the acquisition process can literally continue to the end of one's life, which supports the philosophy behind lifelong learning. Language is embedded in the fabric of life itself, and therefore cannot be limited to language classrooms. In multicultural countries such as the UAE, where English and other languages are used extensively in many aspects of daily life, one will encounter various situations that may require foreign language skills as soon as one steps out of the classroom.

It is not possible to avoid communication, simply because even if we do not communicate with others, we will communicate within ourselves. The use of language, therefore, can be both interpersonal and intrapersonal. In order to increase our efficiency of communication, we need to be equipped with skills that allow us to benefit from the learning opportunities available throughout our life, which highlights the importance of LLL skills. The great breadth of learning throughout life makes it difficult to provide a definitive list of typical skills a lifelong learner should exhibit; however, there have been several attempts to identify some overarching categories of skills, one of which has been developed by Coskun \& Demirel (2012), who put lifelong learning skills under four broad categories: motivation, selfregulation, perseverance, and curiosity. These four categories are discussed in more detail below.

Motivation is "the process used to allocate energy to maximize the satisfaction of needs" (Pritchard \& Ashwood, 2008, p. 6), and it could be intrinsic or extrinsic. Ryan \& Deci (2000, p. 54) define intrinsic motivation in terms of "doing something because it is inherently interesting or enjoyable" and extrinsic motivation in terms of "doing something because it leads to a separable outcome", such as a reward and avoidance of punishment. It seems to be intrinsic motivation that makes learning more enjoyable and meaningful; therefore, it needs to be nurtured through tasks that are relevant and meaningful to learners (McCombs, 1991). Deveci (2013) says that intrinsic motivation can be achieved if empirical use of learning is recognized. Falk (cited in Holt, 2001) observes that language learners' intrinsic motivation increases if they are interested in the people whose language they are learning and keen on integrating into their culture. It is necessary for motivation to be intrinsic so that learning can be lifelong. It is also important to note that motivation is not a static but a dynamic attribute (Shoaib \& Dornyei, 2005): learners will be likely to exhibit different levels of motivation, especially in the case of learning over extended periods of time.

Another category of LLL skills is self-regulation, which involves intrinsically motivated people who are autonomous learners. A definition of autonomy by Holec $(1981$, p. 3) is "the ability to take charge of one's own learning", which emphasizes skills of planning, selecting materials, monitoring progress and assessing learning. From the language learning perspective, Williams \& Burden (1997) state that autonomous learners like to learn a language in a self-regulated way through their chosen skills and strategies. According to Knowles (1975), self-regulated learners possess the skills of diagnosing their learning needs, developing action plans and evaluating the whole learning process. Knapper \& Cropley (2000) add that self-regulated learners are also competent in adapting their learning strategies according to new contexts and have analytical thinking skills allowing them to make links between knowledge from different disciplines.

The third category of LLL skills is perseverance, defined in the Merriam-Webster dictionary as "continued effort to do or achieve something despite difficulties, failure, or opposition". Another definition is given by Rovai $(2003$, p. 1): "the behavior of continuing action despite the presence of obstacles". In terms of learning, these two definitions suggest that persistent individuals endure in the face of difficulties and failure. Bandura (1989) states that individuals with high self-esteem in terms of their learning capacities

Deveci, T. (2015). A comparative study of the lifelong learning propensities of English language learners: nationality, gender and length of study. Learning and Teaching in Higher Education: Gulf Perspectives, 12(1). 
tend to be more persistent and to tackle difficulties more efficiently. On the other hand, those with lower self-esteem tend to surrender easily or get by with an average solution. They will also experience more stress and anxiety, often caused largely by their constant worry concerning their ability to deal with problems. As a result, they will not be very likely to appreciate achievements or to set themselves challenging learning tasks. Pajares (2002) states that if people are doubtful of being able to achieve their targets they may lack the incentive to act or to persist when confronted with difficulties; this will reduce their chances of becoming lifelong learners. When the case of language learners is considered, reasons for reduced perseverance skills may be more noticeable. It is only natural that learners of a foreign language may be more wary of making mistakes due to the fear of being ridiculed. Also, language learners with previous experiences of failure may have lower self-efficacy. Such learners may be in need of persuasion, reinforcement and positive evaluations by their teachers, peers and parents to help them develop a stronger sense of efficacy. Once this is done, their previous negative experiences may have less impact (Dornyei, 1994).

The fourth category of lifelong learning skills is curiosity. Litman (2005) defines curiosity as

a desire to know, to see, or to experience that motivates exploratory behavior directed towards the acquisition of new information. (p. 793)

This definition suggests that for individuals to develop themselves they must feel the need to acquire new knowledge and engage in new learning experiences. This is likely to create intrinsic motivation for learning: curiosity and motivation cannot be divorced from each other. Bruner (1968) highlighted the importance of curiosity long ago by asserting that curiosity enables survival of individuals and species, and stated that "curiosity is almost a prototype of the intrinsic motive" (p. 114). Only when the attitude to learning is persistent can learning become lifelong. This requires a certain level of dedication to learning. Curiosity is an innate attribute, reflected in babies' experience of learning by exploring things. Although curiosity exhibited by infants is generally considered a desired part of life, as people grow older their curiosity may be limited due to various factors such as lack of "uncertainty in the adult's world that needs to be understood" (Piccone, 1999). This, as a result, may hamper the desire to learn more. In order to nurture our inborn quality of curiosity, we need opportunities for critical thinking through asking questions. Although lifelong learners need to be able to form their own questions, teachers can play a role in arousing their students' curiosity through Socratic questioning.

\section{Significance and objectives of this study}

Being able to speak a foreign language helps people become more employable and promotes cultural growth. It can be suggested that individuals would increase their opportunities of employment and cultural growth more easily if they took a lifelong learning approach to language learning. Such an approach would require learners to have a strong orientation towards lifelong learning. Learners at the college level might be expected to possess more of the skills attributed to lifelong learning due to the philosophical underpinnings of tertiary education in general. Higher education institutions promote LLL skills by encouraging students to, inter alia, read academic publications, engage in distance education, make use of technology-based resources (Gunuc, Odabasi \& Kuzu, 2012). However, university entrance regulations in certain education systems require students to sit long, centralized exams which promote severe competition amongst the candidates, leading to an overall approach of rote learning and surface learning (Kellaghan, Madaus \& Raczek, 1996). Turkey has such a system, and the Education Ministry's Undergraduate Selection Examination (OSS), is one example of such an exam. A similar system exists in the $U A E$, where students wishing to enroll in certain universities are required to sit a central exam, primarily the Common Educational Proficiency Assessment (CEPA). In both contexts, English is the most

Deveci, T. (2015). A comparative study of the lifelong learning propensities of English language learners:

nationality, gender and length of study. Learning and Teaching in Higher Education: Gulf Perspectives, 12(1).

http://Ithe.zu.ac.ae 
common foreign language; additionally, many private universities, and some state universities have English as the medium of instruction. Once admitted to a university, students entering these institutions take a proficiency exam to determine their level of English. Should their level of proficiency be found inadequate, they are placed in preparatory programmes commonly known as foundation programmes or foundation year.

Having spent 14 years in two different English preparatory programmes in Turkey and two years in a similar programme in the UAE, I have had the constant feeling that a number of students in both contexts perceive foreign language learning as an imposition on them, which reduces their general love of learning. I feel that this negative feeling may partly be due to a lack of aptitude for LLL. This study, therefore, was conducted with the hope that it would shed some light on language learners' characteristics in terms of their LLL orientations. This might give educational planners and instructors some indications of how to better cater for students' needs and promote their engagement in LLL skills. With the belief that an awareness of possible reasons for learners' lack of LLL skills would help educators plan instructional activities accordingly, this research also aimed to identify whether or not learners' nationalities, genders and length of study might play a role in determining their LLL orientations. The importance mentioned above of considering local contexts in teaching/learning foreign languages also gave this study the impetus to describe the LLL orientations of students in two university foundation programmes, and suggest ways of promoting language learning from the LLL perspective. With these aims in mind, the following research questions were asked:

1) How do the lifelong learning propensities of Turkish and Emirati students learning English as a foreign language compare?

2) Do the students' lifelong learning orientations differ according to gender?

3) Do the students' lifelong learning orientations differ according to length of study?

\section{Method}

\section{The respondents}

A total of 108 students participated in this study. 61 of the participants (56\%) were Emirati Arabs studying English as a foreign language at the Petroleum Institute (PI), Abu Dhabi. On the other hand, 47 of the participants (44\%) were Turkish native speakers learning English as a foreign language at Sabanci University (SU), Istanbul. Female participants accounted for $60 \%$ of the students. 40 of these students (62\%) were Emirati while 25 of them (38\%) were Turkish. On the other hand, the male students accounted for $40 \%$ of the participants. 22 of the male students (51\%) were Turkish, and 21 of them (49\%) were Emirati. The ages of the participants varied from 17 to 23, with a mean age of 19.

The students in both institutions are placed into different levels of the foundation programmes depending on their levels of English on entry, and therefore that some spend longer periods of time in their programmes than others. In general, the Turkish participants' overall level of English appears to be higher than that of the Emirati participants, because of which they may leave their foundation programme sooner.

Only students placing at an intermediate level of English or above participated in the study, in order to ensure that full understanding of the language used in the research tool was not hindered by a lack of competency.

Deveci, T. (2015). A comparative study of the lifelong learning propensities of English language learners: nationality, gender and length of study. Learning and Teaching in Higher Education: Gulf Perspectives, 12(1). 


\section{Data collection and analysis}

The data for this study were collected using a research tool comprising three sections. The first section aimed to collect data on demographics: gender, nationality and length of study in the current programme. The second section was based on the Lifelong Learning Tendency Scale (LLLTS), developed by Coskun \& Demirel (2012). The original language of LLLTS is Turkish; however, the English version of the instrument was created by the researcher of this current study (see Appendix). In translating, certain statements were slightly adjusted to reflect language learning experience from the LLL perspective, one example of which is 'One of my priorities in life is to achieve personal development by improving my English and continuously learning new things and skills.' In order to ensure its validity, the instrument was cross-checked by an independent language teacher who is a bilingual speaker of English and Turkish. After this, the instrument was piloted with 10 English language learners in PI and another 5 Turkish English language learners in SU.

The validity and reliability of the original LLLTS were tested by the developers of the original scale and the Cronbach alpha internal consistency coefficient was found to be .89 , indicating that the instrument was reliable. Additionally, LLLTS's reliability has been confirmed by other researchers who used it in their studies investigating LLL orientations of Turkish university students (Garipoglu, 2013; Arsal, 2011).

As described earlier, LLLTS comprises four subsections: a) motivation (6 items), b) perseverance (6 items), c) self-regulation (6 items), and d) curiosity ( 9 items). Some of the statements for these subsections are as follows:

Statement 5 (Motivation): Learning new things all the time is a passion for me.

Statement 12 (Perseverance): Even if what I am trying to learn is difficult and confusing, I do my best to learn it.

Statement 18 (Self-regulation): I find it stressful to evaluate my own learning and this makes learning new things difficult for me.

Statement 23 (Curiosity): I do not spend time learning about something just because I am curious about it.

As seen in the sample statements above, the LLLTS includes both positive and negative statements. The respondents were asked to indicate their level of agreement or disagreement with the given statements on a six-point Likert scale with response choices ranging from 6 (strongly agree) to 1 (strongly disagree). The negative statements were reverse scored. The minimum score possible for the twenty-seven items is $27(27 \times 1)$, and the maximum score is $162(27 \times 6)$. The midway score is $94.5(27 \times 3.5)$, indicating a neutral orientation.

Using a translated version of an instrument may bring limitations. Ervin \& Bower (1952) raised concerns long ago over whether or not it is better to use the native language of the participants of a study instead of English. They pointed out the unavailability of researchers with the necessary linguistic and sociological skills as a limiting factor, which was the case in this study with Arabic in particular. Also, administration of the English version of LLLTS to both Arabic and Turkish participants in this study was believed to help facilitate the comparison of the two data sets from different local contexts. Another reason for administering LLLTS in English was merely because the students filled it in during class time, when institutional policy requires that they use English.

Deveci, T. (2015). A comparative study of the lifelong learning propensities of English language learners: nationality, gender and length of study. Learning and Teaching in Higher Education: Gulf Perspectives, 12(1). 
The final section of the research tool comprised six open-ended questions (see Appendix), which provided the researcher with qualitative data. This helped gather some in-depth information about language learners' beliefs and experiences regarding LLL, in order to help understand causal connections and clear up any ambiguities (Silverman, 2010). In this study, the section for qualitative data was optional; 35 students (15 from P.I. and 20 from S.U.) chose to answer the six open-ended questions in this section.

The responses derived from the last section of the research tool were analyzed using a coding scheme which helped identify the emerging themes. An independent educator was consulted on the accuracy of the coding.

SPSS (Version 18.0; SPSS Inc., Chicago, USA) was used to analyze the quantitative data. All numerical variables were first tested for test assumptions such as normality, and then according to assumptions. Additionally, Student's t-test was used for nationality and the Mann-Whitney U-test was used to compare the data according to gender. On the other hand, the Kruskal-Wallisnon-parametric ANOVA test was used to compare the data according to duration since three independent samples of unequal size were compared, and the measurement variable did not meet the normality assumption (McDonald, 2009). A p-value at 0.05 was considered in determining statistically significant differences.

\section{Results}

This section reports the results of data collected through LLLTS and the six open-ended questions. Accordingly, the results are categorized as the quantitative data from LLLTS and the qualitative data from the open-ended questions.

\section{Data from LLLTS}

The first research question aimed to identify the lifelong propensities of Turkish and Emirati students learning English, and asked how the two national groups compared to each other. The analysis of the data gathered using LLLTS in response to this question is seen in Table 1.

Table 1: Turkish and Emirati students' LLLTS scores.

\begin{tabular}{|c|c|c|c|c|c|c|c|}
\hline & \multicolumn{3}{|c|}{$\begin{array}{c}\text { Turkish Students } \\
(\mathrm{N}=47)\end{array}$} & \multicolumn{3}{|c|}{$\begin{array}{l}\text { Emirati Students } \\
(\mathrm{N}=61)\end{array}$} & \\
\hline Sub-skills & $\begin{array}{l}\text { Min.- } \\
\text { Max. }\end{array}$ & Mean & SD & $\begin{array}{l}\text { Min.- } \\
\text { Max. }\end{array}$ & Mean & SD & $\mathbf{p}$ \\
\hline Motivation & $23-36$ & 30.47 & 3.021 & $16-36$ & 30.77 & 4.084 & 0.350 \\
\hline Perseverance & $18-35$ & 26.87 & 4.079 & $17-30$ & 26.28 & 4.723 & 0.494 \\
\hline Self-regulation & $14-36$ & 25.77 & 5.296 & $8-35$ & 20.92 & 8.202 & 0.003 \\
\hline Curiosity & $18-52$ & 36.43 & 8.018 & $9-51$ & 29.46 & 10.001 & 0.001 \\
\hline Total Score & $88-150$ & 119.53 & 15.404 & $70-151$ & 107.43 & 19.618 & 0.001 \\
\hline
\end{tabular}

Table 1 shows that the overall LLLTS score for these Turkish learners (mean=119.53) was higher than that of the Emirati learners (mean=107.43). The statistical analysis done to determine whether or not there was a significant difference between these scores revealed an affirmative result $(p=0.001)$, which shows that the Turkish respondents had a somewhat higher aptitude for LLL compared to their Emirati counterparts. In particular, the Turkish learners' scores for the sub-skills of self-regulation (mean=25.77) and curiosity (mean=36.33) were found to be significantly higher than those of the Emirati students

Deveci, T. (2015). A comparative study of the lifelong learning propensities of English language learners: nationality, gender and length of study. Learning and Teaching in Higher Education: Gulf Perspectives, 12(1). 
(means $=20.92$ and 29.46 respectively) $(p=0.003, p=0.001)$. That is, the Turkish students appeared to be more curious about language learning and more skilled in terms of regulating their learning. However, no significant difference was found between the two groups for the motivation and perseverance sub-skills $(p=0.350, p=0.494)$.

The second research question asked whether gender made a difference in language learners' LLL orientations. Table 2 outlines the statistical analysis results in response to this question.

Table 2: LLLTS scores by gender.

\begin{tabular}{|c|c|c|c|c|c|c|c|}
\hline & \multicolumn{3}{|c|}{$\begin{array}{c}\text { Male } \\
(\mathrm{N}=43)\end{array}$} & \multicolumn{3}{|c|}{$\begin{array}{l}\text { Female } \\
(\mathrm{N}=65)\end{array}$} & \\
\hline Sub-skills & $\begin{array}{l}\text { Min- } \\
\text { Max }\end{array}$ & Mean & SD & $\begin{array}{l}\text { Min- } \\
\text { Max }\end{array}$ & Mean & SD & $\mathbf{p}$ \\
\hline Motivation & $16-36$ & 30.56 & 3.899 & $22-36$ & 30.69 & 3.500 & 0.960 \\
\hline Perseverance & $17-35$ & 26.86 & 4.033 & $16-34$ & 26.32 & 4.714 & 0.541 \\
\hline Self-regulation & $9-36$ & 23.79 & 7.324 & $8-35$ & 22.52 & 7.558 & 0.390 \\
\hline Curiosity & $11-52$ & 33.37 & 9.066 & $9-51$ & 31.91 & 10.262 & 0.449 \\
\hline Total Score & $84-150$ & 114.58 & 15.957 & 70-151 & 111.45 & 20.520 & 0.375 \\
\hline
\end{tabular}

Table 2 shows that there were no statistically significant differences between the total scores or any sub-skill scores between male participants' and female participants' LLL orientations: both female and male students showed a moderate aptitude for LLL. It is true that male learners' overall scores and their scores for each element of LLL are slightly higher than those of female learners, with the exception of motivation; however, this difference did not reach a level of statistical significance.

The final research question asked whether or not the participants' LLL orientations differed as their length of study increased. The results for this question are given in Table 3.

Table 3: LLLTS scores by duration of study.

\begin{tabular}{|c|c|c|c|c|c|c|c|c|c|c|}
\hline & \multicolumn{3}{|c|}{$\begin{array}{c}<6 \text { months } \\
(N=42)\end{array}$} & \multicolumn{3}{|c|}{$\begin{array}{c}\text { 6-12 months } \\
(\mathrm{N}=44)\end{array}$} & \multicolumn{3}{|c|}{$\begin{array}{c}>12 \text { months } \\
(\mathrm{N}=22)\end{array}$} & \\
\hline Sub-skills & $\begin{array}{l}\text { Min- } \\
\text { Max }\end{array}$ & Mean & SD & $\begin{array}{l}\text { Min- } \\
\text { Max }\end{array}$ & Mean & SD & $\begin{array}{l}\text { Min- } \\
\text { Max }\end{array}$ & Mean & SD & p \\
\hline Motivation & $16-36$ & 31.33 & 4.258 & $26-36$ & 30.64 & 2.894 & $22-36$ & 29.32 & 3.524 & 0.035 \\
\hline Perseverance & $16-34$ & 26.24 & 5.300 & $18-34$ & 26.80 & 4.140 & $22-35$ & 26.59 & 3.217 & 0.853 \\
\hline Self-regulation & $9-35$ & 24.43 & 7.982 & $12-36$ & 23.07 & 6.582 & $8-35$ & 20.27 & 7.642 & 0.092 \\
\hline Curiosity & $11-51$ & 31.40 & 9.693 & $9-52$ & 34.72 & 9.770 & $16-43$ & 30.09 & 9.496 & 0.095 \\
\hline Total Score & $83-151$ & 113.4 & 18.893 & $70-150$ & 115.23 & 18.763 & $75-133$ & 106.27 & 18.145 & 0.219 \\
\hline
\end{tabular}

Table 3 shows that the participants' total score of the third category ( $>12$ months) (mean=106.27) was lower than the scores for the learners in the other two groups (mean=113.4 and mean=115.23) despite a lack of statistically significant difference between the data sets $(p=0.219)$. This was also the case with the sub-skills perseverance, self-regulation and curiosity. The learners learning English for the longest duration of time scored lower for the given sub-skills, which was despite the lack of statistically significant differences between the scores for each sub-skills across the three different durations. The

Deveci, T. (2015). A comparative study of the lifelong learning propensities of English language learners: nationality, gender and length of study. Learning and Teaching in Higher Education: Gulf Perspectives, 12(1). 
only statistically significant difference detected was regarding the motivation sub-skill where the third group of learners' mean score (mean $=29.32$ ) was different at a significant level $(p=0.035)$. Further data analysis for this sub-skill revealed that the difference between the first group's score (mean=31.33) and the last group's (mean=29.32) was significantly different $(p=0.015)$, suggesting that those who had spent more than 12 months studying English had fewer motivational skills compared to the other two group of learners.

\section{Data from the six open-ended questions}

Table 4 shows the frequency of each theme identified in the analysis of the open-ended question responses, and the percentage of commenting students in each sub-group who mentioned the theme.

Table 4: Comments by LLL theme and student sub-group.

\begin{tabular}{|c|c|c|c|c|c|c|c|c|}
\hline \multirow{3}{*}{ Sub-skills } & \multirow{3}{*}{ Themes } & \multicolumn{2}{|c|}{ Nationality } & \multicolumn{2}{|c|}{ Gender } & \multicolumn{3}{|c|}{ Length of Study } \\
\hline & & $\begin{array}{l}\text { Turkish } \\
(\mathrm{N}=20)\end{array}$ & $\begin{array}{l}\text { Emirati } \\
(\mathrm{N}=15)\end{array}$ & $\begin{array}{l}\text { Male } \\
(\mathrm{N}=14)\end{array}$ & $\begin{array}{l}\text { Female } \\
(\mathrm{N}=21)\end{array}$ & $\begin{array}{c}<6 \\
\text { months } \\
(\mathrm{N}=10)\end{array}$ & $\begin{array}{c}6-12 \\
\text { months } \\
(\mathrm{N}=18)\end{array}$ & $\begin{array}{c}>12 \\
\text { months } \\
(\mathrm{N}=7)\end{array}$ \\
\hline & & $f(\%)$ & $f(\%)$ & $f(\%)$ & $f(\%)$ & $f(\%)$ & $f(\%)$ & $f(\%)$ \\
\hline \multirow[t]{2}{*}{ Motivation } & Love of learning & $12(60)$ & $9(60)$ & $8(57)$ & $13(62)$ & $6(60)$ & $12(67)$ & $3(43)$ \\
\hline & Job security & $17(85)$ & $4(27)$ & $6(43)$ & $15(71)$ & $8(80)$ & $10(56)$ & $3(43)$ \\
\hline \multirow[t]{3}{*}{ Perseverance } & $\begin{array}{l}\text { Reflection on } \\
\text { experiences }\end{array}$ & $14(70)$ & $10(67)$ & $7(50)$ & $17(81)$ & $6(60)$ & $13(72)$ & $5(71)$ \\
\hline & $\begin{array}{l}\text { Attitude toward } \\
\text { failure }\end{array}$ & $12(60)$ & $8(53)$ & $7(50)$ & $13(62)$ & $6(60)$ & $10(56)$ & $4(57)$ \\
\hline & Revision of goals & $13(65)$ & $4(27)$ & $6(43)$ & $11(52)$ & $5(50)$ & $8(45)$ & $4(57)$ \\
\hline \multirow[t]{3}{*}{ Self-regulation } & $\begin{array}{l}\text { Assessment of own } \\
\text { learning }\end{array}$ & $16(80)$ & $5(33)$ & $9(64)$ & $12(57)$ & $7(70)$ & $11(61)$ & $3(43)$ \\
\hline & $\begin{array}{l}\text { Accessing learning } \\
\text { resources }\end{array}$ & $13(65)$ & $7(47)$ & $8(57)$ & $12(57)$ & $5(50)$ & $10(56)$ & $5(71)$ \\
\hline & $\begin{array}{l}\text { Adaptation of } \\
\text { learning strategies }\end{array}$ & $8(40)$ & $2(13)$ & $3(21)$ & $7(33)$ & $2(20)$ & $6(33)$ & $2(29)$ \\
\hline \multirow[t]{2}{*}{ Curiosity } & Asking questions & $10(50)$ & $5(33)$ & $8(57)$ & $7(33)$ & $4(40)$ & $8(45)$ & $3(43)$ \\
\hline & $\begin{array}{l}\text { Communicating } \\
\text { with others }\end{array}$ & $14(70)$ & $8(53)$ & $8(57)$ & $14(67)$ & $7(70)$ & $11(61)$ & $4(57)$ \\
\hline
\end{tabular}

\section{Motivation}

Data analysis revealed two themes: love of learning and job security. Intrinsic motivation as a motivational skill was mentioned by equal percentages of students of each nationality (60\%). However, ensuring a secure career life was invoked by more Turkish students (85\%) compared to Emirati students (27\%), for example: "If I learn English well, I will have more job opportunities" (Turkish student)/ "English is definitely important at work, but it is not a barrier for me to find a job" (Emirati student).

Female participants of both nationalities seemed to mention these themes more frequently than their male counterparts. Desire for learning motivated $62 \%$ of the female students while $57 \%$ of the male learners mentioned it as a contributing factor. A female student, for example, said "English will make me

Deveci, T. (2015). A comparative study of the lifelong learning propensities of English language learners: nationality, gender and length of study. Learning and Teaching in Higher Education: Gulf Perspectives, 12(1). 
more powerful when I start working". Similarly, job security was more of a motivational factor for the female students than the male students ( $71 \%$ and $43 \%$ respectively). One female student remarked that speaking English would help her in the male dominated work-life.

When the length of study is considered, it is seen that the students who had been studying for the longest period of time tended to have lower motivational skills (43\%). Some of these students mentioned their frustration at not being able to complete the preparatory year. One learner said: "The exams I have had to take make me lose my interest in the language"; another learner made a similar comment:

I want to pass my exams and go to my faculty. I will learn more English there, but I feel I am stuck here. I don't want to see English course-books.

It is evident from these excerpts that the motivation of the learners tended to be reduced as a result of frustration; this seemed to be caused by their experience of assessment in particular.

\section{Perseverance}

An ability to reflect was an important factor contributing to both Turkish and Emirati students' scores for perseverance ( $70 \%$ and $67 \%$ respectively). Students appeared to have reflected on their learning experiences. One Turkish student said reflection helped him become aware of his strengths, which motivated him to try harder; similarly, some Emirati students mentioned that it was easier to prepare for future classes when they revised previous lessons.

When asked what kept her from giving up in the face of difficulties, one Emirati student explained that she could learn from her mistakes and avoid repeating them. A similar comment was made by a Turkish student: "Realizing my mistakes matures me, and I feel stronger". These responses show that the students' positive attitude towards failure helped them persevere.

More Turkish students (65\%) were found to revise their goals than did their Emirati counterparts. Some Turkish students said they would not mind altering their goals if they didn't help them succeed, and they set goals that would help them learn. To exemplify, one student said "I sometimes change what I planned to do if I have problems learning something difficult". Although similar comments were made by some Emirati students, some of them were less flexible with revising goals. One student expressed that he experienced feelings of anger when unable to achieve his goals and would tenaciously stick to his original plans. Although this might help him persevere, the lack of skills in revising goals could lead to disappointment; therefore, a certain level of flexibility may be a desired quality in terms of perseverance.

When gender is considered, the female learners appeared to be more equipped with perseverance skills, despite the lack of statistically significant difference in the quantitative data. Firstly, more of the female students (81\%) appeared to reflect on their experiences than the male students (50\%). Two female students mentioned the awareness they developed because of reflection. One participant said: "Seeing how little I knew before shows I am more able now." Also, the female students offered more positive comments about failure than their male counterparts ( $62 \%$ and $50 \%$ respectively); one female participant stated: "I am not happy with mistakes, but I can't learn to walk without falling."

Revision of goals also emerged more often in the female students' responses. Just over half of the female students (52\%) mentioned their willingness to revise learning aims to help them persevere. One participant recalled an occasion when her achievement of an easier goal encouraged her to strive for a

Deveci, T. (2015). A comparative study of the lifelong learning propensities of English language learners: nationality, gender and length of study. Learning and Teaching in Higher Education: Gulf Perspectives, 12(1). 
more difficult one. Similar comments were made by some male learners indicating that they were prepared to increase or decrease the difficulty level of goals if necessary.

The data provided by the students from different durations of study showed different levels of perseverance skills. Those studying English for less than six months expressed reflection as a contributing factor less often $(60 \%)$ than the other two groups of learners $(72 \% \& 71 \%)$. Their comparatively shorter length of exposure to language learning experience may be one reason for this. The students with more learning experience may have engaged in reflection more often. Those with more learning experience may have also experienced fewer failures which resulted in fewer opportunities to think critically. The students learning English for longer than a year seemed to have the interest and the skills necessary to advance their language skills once they could start at their departments, which is reflected in a student's response: "I know what I need to do to succeed, but only if I could pass the exams."

\section{Self-regulation}

With respect to nationality, the Turkish respondents expressed self-regulation skills more often than the Emirati students. For instance, more Turkish students (80\%) assessed their learning. Their instructors made use of 'Can-do statements' to promote self-assessment. These students also took mock exams to identify their strengths and weaknesses. Only a few Emirati students (33\%) used self-assessment tools such as TOEFL preparation books. $65 \%$ of the Turkish students were identified to regulate their learning trying to access learning resources such as the Internet and library books. However, $47 \%$ of the Emirati students took advantage of self-access materials, mainly located in the library.

Eight Turkish students (40\%) were found to alter their learning strategies to achieve better results. This was done by only $13 \%$ of the Emirati students. A Turkish student indicated that he tried different reading strategies: "An exam taught me I cannot read every word. I should learn to do skimming." adaptation of learning strategies was also evident in an Emirati students' response: "I used to underline things. Now I make notes on texts, too."

In terms of gender, fewer female participants (57\%) than male participants (64\%) assessed their own learning, but more of them (33\%) said they adapted their learning strategies in the face of challenges. Equal percentages of female and male students used their skills by accessing learning resources (57\%).

Although the quantitative data analysis did not reveal significant differences between the learners' selfregulations skills regarding length of study, some differences emerged when the qualitative data were analyzed. Firstly, assessment of one's own learning progress was expressed by $70 \%$ of the students learning English for less than six months, compared to $61 \%$ and $43 \%$ in the two other categories. One student in this category mentioned his feeling of empowerment resulting from self-assessment. Secondly, almost three quarters (71\%) of the participants learning English for longer than a year found it easier to access learning resources compared to the participant in the other two categories (50\% and $56 \%$ ). This may be attributed to their relatively higher amount of exposure to learner training experiences. Lastly, more of the learners in the second category (between 6 and 12 months) (33\%) stated that they adapted their learning strategies compared to those in the first category $(20 \%)$ and the third category (29\%).

\section{Curiosity}

According to Table 4, Turkish students displayed comparatively more curiosity than the Emirati students. While half of the Turkish students asked questions about how certain aspects of language learning

Deveci, T. (2015). A comparative study of the lifelong learning propensities of English language learners: nationality, gender and length of study. Learning and Teaching in Higher Education: Gulf Perspectives, 12(1). 
would benefit them, only $33 \%$ of the Emirati students tended to ask questions. Similarly, compared to their Emirati counterparts (53\%), more Turkish students (70\%) thought their communication with others made them curious about other cultures and foreign languages. The majority of the Turkish students mentioned their interaction with foreigners on the Internet as a contributing factor. Their involvement in social websites gave them the motivation to learn English. One student said: "I'd like to learn English so I can follow more people on Twitter." Some Emirati students pointed out the multicultural nature of their country giving them the incentive to learn English. In the words of an Emirati student:

We have people from all around the world, and they speak English. If my English is good, I can learn about them.

Regarding gender, $57 \%$ of the male respondents said that they ask questions, while only $33 \%$ of the female students voiced their curiosity in this way. However, the number of the female respondents motivated to learn English by communicating with others was higher than that of the male respondents (57\% vs $67 \%)$.

In terms of length of study, there were no major differences among the three groups of learners in relation to showing their curiosity by asking questions. However, those in the second group (between 6 and 12 months) seemed to ask questions slightly more often (45\% vs 40\%, 43\%). The number of learners in the first group ( $<6$ months) who expressed their desire to communicate with others was markedly higher than those in the other groups ( $70 \%$ vs $61 \%, 57 \%)$.

\section{Discussion}

This study aimed to identify the LLL orientations of Turkish and Emirati learners of English language. Comparisons were made between nationalities, genders and lengths of study in relation to their LLL orientations.

Both Turkish and Emirati students were found to hold a moderate level of propensity for LLL. This shows that they had the inclination for LLL, but were in need of improving related skills to enhance their chances of learning English on a long-term basis. The comparison of the data sets showed that the Turkish learners' overall LLL score was higher than that of the Emirati students at a statistically significant level. The same was true for the self-regulation and curiosity sub-skills. The Turkish students also scored slightly higher for the motivation and perseverance sub-skills than did the Emirati students, although there were no statistically significant differences between the two groups of students.

The lack of studies concerning language learners' LLL orientations in the literature prevents comparisons of the results of this research to previous research results. While this may be considered a limitation for the current study, it does suggest that the study is a genuine and worthwhile contribution to understanding about LLL. However, there have been several studies conducted on the different subskills identified as contributing factors to LLL, which are briefly outlined below.

The finding of this research which revealed Emirati students' comparatively lower motivation for language learning, as compared to the Turkish students, has been echoed in several studies conducted into Arab students' learning orientations. For instance, Javid, Al-Asmari \& Farooq (2012) studied Arab university students in Saudi Arabia, where learners can be considered comparable to Emirati students due to their similar cultures, environments, traditions and educational systems. They found that Saudi students were more extrinsically than intrinsically motivated, which may suggest lower tendencies for LLL since motivation could be expected to be intrinsic for learning to be lifelong. Arab learners of English in Yemen were also found to have mainly extrinsic motivation triggered by instrumental reasons (Al-

Deveci, T. (2015). A comparative study of the lifelong learning propensities of English language learners: nationality, gender and length of study. Learning and Teaching in Higher Education: Gulf Perspectives, 12(1). 
Tamimi \& Shuib, 2009). In their study of the reasons why Arab students in Beirut lost motivation, Bahous et al. (2011) found that perceived overemphasis on writing skills, lack of novel learning experiences and missing links between learners' future professions and the content of the syllabi played a role in undermotivation. On the whole, these studies seem to suggest that Arab learners' limited intrinsic motivation, mainly caused by lack of meaningful learning experiences, is likely to inhibit their potential to become lifelong learners. McCombs (1991) emphasizes that lifelong learning and motivation are indistinguishable to the extent that " $t$ ]he motivated person is a lifelong leaner, and the lifelong learner is a motivated person" (p. 117).

The results of this study did not reveal any statistically significant differences between male and female students' motivation skills. Similarly, a recent study in Pakistan by Akram \& Ghani (2013) did not show any significant differences in male and female students' motivation to learn English. On the other hand, Schmidt et al. (1996) in the Egyptian context and Semmar (cited in Javid at al., 2012) in the UAE context found that female students had a greater potential for motivation to learn than male students. In the earlier study, the female students were observed to have more intrinsic motivation. Likewise, Erten (2009) identified more intrinsic motivation in Turkish female students of English and reached the conclusion that this influenced positively their engagement in academic studies. Similarly, research done into university foundation programme students' orientations in Turkey indicated that female students had more intrinsic motivation and higher self-efficacy compared to male students (Yurtseven et al., 2013; Sad \& Gurbuzturk, 2009). The fact that some of these studies showed similar results while the one by Akram \& Ghani (2013) showed contradicting results suggests that gender may not always be a determining factor in language learners' motivation for learning. The variations in the contexts in which these studies were conducted may also have led to different results.

When the participants' length of study is considered, it was found that the motivation score of the students learning English for more than a year was lower than those of the other two groups of learners at a statistically significant level. This suggests that the participants decreased their motivation for LLL as their length of study increased, which could affect their potential as lifelong learners negatively. It is suspected that such a trend may be due to the distress experienced by the learners too impatient to start their majors. It could also be that the linguistically less able students may have had to spend more time in the foundation programme with a decreasing effect on their LLL skills. This was also evident in the qualitative data collected from some of the students who expressed their feelings of being confined to their foundation programmes. This may mean that learners would be likely to increase their scores once they are engaged in their interest areas. The qualitative data showed that these students' length of study was extended mainly because of their failures in their exams, which seems to make the case for the decrease in their self-efficacy and therefore in their motivation. Bandura (1991) notes that selfefficacy reduced by failure would lead to a decrease in the amount of effort one makes. Schunk (cited in Bolhuis, 2003) supports this by saying that students with lower self-esteem tend to have less involvement in learning, and are less likely to persist when they encounter problems. The participants' lower scores for the persistence skill in this study, therefore, could be attributed to their previous experiences of failure. It also seems to support the belief that individuals' sense of previous failure can have a determining effect on their motivation (Skinner, 1995).

The finding of this research regarding the Turkish learners' moderate aptitude for self-regulation was also observed by Barlas (2012), who studied the autonomous learning orientations of students training to become English language teachers. She found that the trainee teachers had a propensity for deciding on their learning methods and assessing their own progress. Kocak's study (2003) also indicated some self-regulatory behaviors exhibited by Turkish students; however, they were found to have a strong

Deveci, T. (2015). A comparative study of the lifelong learning propensities of English language learners: nationality, gender and length of study. Learning and Teaching in Higher Education: Gulf Perspectives, 12(1). 
inclination for assuming responsibilities for deciding on what to and how to learn outside of class. Although this may be regarded as an important quality, lifelong learners are expected to exhibit such skills in the presence of their instructors as well. Sad \& Gurbuzturk (2009) found that Turkish students had low self-regulatory orientations due to their motivation being triggered only by extrinsic motivation created by external factors. The results of these studies together with those of this current study seem to suggest that Turkish learners tend to have some aptitude for self-regulatory learning with a potential to help them become lifelong learners, but they need to improve their self-regulation skills to be more purposeful in their orientations towards LLL. It also appears that intrinsically motivated learners might be at an advantage in terms of enhancing their self-regulation skills for LLL.

Some other studies investigated self-regulation skills of Arab learners. In her study comparing Arab students to American students on a distance learning program, Al-Harthi (2007) found that Arab students reported lower levels of self-regulation. Their scores in planning, monitoring and managing time and learning environment were markedly lower than their American counterparts. However, the Arab students used their skills of asking for help in their attempts to persevere when they had difficulties. This could be said to have a positive effect on students' LLL skills since it helps overcome difficulties. Al-Harthi (2007) suggests that this difference between the two cultures may be due to the individualistic nature of American culture, making American students seem more autonomous. The Arab students' tendency to ask for help as a way of regulating their learning may also be true for Turkish learners, since the culture in Arab countries is collectivist, and Turkish culture is found to have some characteristics of collectivist cultures (Suh et al., 1998). The collectivist nature of a culture may be argued to encourage its members to ask for help when needed, which provides different resources for LLL.

The results of this study indicated that gender was not a determining factor in learners' orientation to self-regulation skills. Similarly, Kocak (2003) also found that gender was not a significant factor in determining Turkish learners' orientations of self-regulation skills when learning a foreign language. However, the male students tended to leave the responsibility of deciding on objectives to their teachers while the female students prefered to share this responsibility.

Despite the abovementioned similarities between the findings of earlier research and this current study, some previous research has also yielded some contradicting results to the findings. Barlas (2012) found that the Turkish female English language teacher trainees had more self-regulation skills than the male trainees. Similarly, Baylan (2007) and Sad \& Gurbuzturk (2009) showed that female language learners had more tendencies for self-regulatory learning than male students. In addition, Yalcin \& Yalcin (2005) revealed that female students were better equipped with language learning strategies that helped them to regulate their own learning and deal with difficulties, increasing their academic success.

Turkish students' moderate level of curiosity identified in this study has been echoed in some previous research. For example, in her study investigating the difficulties Turkish university learners encountered, Sertcekic (2008) found that learners' lack of curiosity about the culture of the people whose language they were learning reduced their intrinsic motivation, and reduced their self-regulation skills. As a result, this inhibited their overall progress. Ozturk \& Gurbuz (2013) also found that Turkish students learning English at a public university had a moderate level of integrative motivation and therefore limited curiosity about English language, and native English speakers' cultures. Taken together, the results of this study seems to give credence to the argument that curiosity leads to more intrinsic motivation (Bruner, 1968), which can be fueled by learners' genuine interest in the culture of the language they are learning (Falk cited in Holt, 2001).

Deveci, T. (2015). A comparative study of the lifelong learning propensities of English language learners: nationality, gender and length of study. Learning and Teaching in Higher Education: Gulf Perspectives, 12(1). 


\section{Conclusion and recommendations}

The attention LLL has attracted recently has increased to the extent that no profession seems to be immune to it. People's chances of employability can be increased with their skillful use of English, which seems to be the dominant language in the present age of globalization. Therefore, it can be argued that fluent speakers of English can access greater learning and employment opportunities throughout their lives. Hence, it seems to be necessary for individuals to adopt a lifelong approach to language learning. However, it would be wrong to expect all students to be equipped with LLL skills when they first start studying in foundation programmes. Teachers would benefit from identifying their students' orientation to learning in general and LLL in particular. This is the main reason why this descriptive research was carried out. It aimed to describe the situations in which Arab and Turkish foreign language learners approached learning in their local contexts of university education from the LLL perspective, and how their gender and length of study seemed to affect their orientations. Increasing teachers' understanding of their language students' LLL orientations can reduce teachers' frustrations if they teach students with different levels of aptitude for LLL than their own LLL aptitudes. Korhonen (2010) states that recognition of individuals' perceptions of learning contributes to our development of intercultural competence, which helps develop intercultural sensitivity (Bennett, 1998). This, in turn, would create more opportunities for improving students' and teachers' LLL skills.

To help students improve their aptitude for LLL, several actions can be taken. In terms of motivational skills, Al-Othman \& Shuqair (2013) suggest that Arab students' intrinsic motivation for language learning in the Gulf States can be increased by considering their needs, and encouraging them to use English outside the classroom in their education settings. This does not mean that local students should be encouraged to mainly speak a language other than their native language in their daily life. It is argued that imposing foreign languages on Arabic in the Gulf region is likely to hamper the development of national identity among young people in particular (Mohammed, 2008). Kanik (2002) also underlines the importance of arousing students' interest and curiosity about the teaching materials by raising their awareness of how they relate to their future needs. In cases of English language learning for academic purposes, the students can be provided with showcases of particular skills they need to acquire in order to survive in an English medium university. It is important to note that some of the skills they develop for academic studies can be transferred to their lives beyond university. For instance, presentation skills would be beneficial in their future professionals.

This study found that the students who learned English for longer periods of time tended to lose their motivation, and this was caused by their frustration due to failing their English exams. Considering their potential orientation for LLL, these students can be helped by identifying the exam-related issues from which they are suffering. Their failure and negative feelings may be caused by exam anxiety instead of linguistic reasons, which would be addressed best by a student counselor. The types of assessment can also be reconsidered to reduce stress. Herman et al. (1992) state that standardized tests may not always reflect realistic goals for student learning, and therefore alternative assessment systems need to be considered. They note that such systems require students to create something, tap higher-level thinking skills, invoke real-world applications and include tasks that represent meaningful instructional activities. In this current study, it also appeared that these students were impatient to start content classes in their departments. In order to meet these students' needs, the target foreign language could be taught using materials adapted from their future subject areas. This could help students see the empirical use of the target language and keep them intrinsically motivated.

Deveci, T. (2015). A comparative study of the lifelong learning propensities of English language learners: nationality, gender and length of study. Learning and Teaching in Higher Education: Gulf Perspectives, 12(1). 
This study also found that the participants' self-regulation skills need to be promoted so that they could have higher levels of LLL orientation. Language learners' self-regulation skills can be promoted by involving them in all stages of instructional design. In the planning stage, for example, needs analyses can be done with students' contributions. To this end, students' reasons for learning English can be acquired. If the target group of learners has had previous experience with foreign language learning, they may be asked about the particular difficulties they faced. In the evaluation stage, on the other hand, the students can be shown possible 'can-do statements' at the beginning, middle and end of a course to help them evaluate their own learning. If students' self-confidence is increased regarding their capabilities of managing their own learning, they will be more willing to take active roles. For example, when encouraged to set their own goals, they may assume greater responsibility for undertaking learning activities to meet them. Deveci (2013) observes that training students to do reflective thinking is helpful as they are then more likely to notice hidden reasons for failure as well as success. With this in mind, language learners can be encouraged to record their spoken outputs and listen to them to notice their strengths and weaknesses. Their teachers' guiding questions could then help them focus on particular aspects of their performance.

\section{Future directions}

While this current study was primarily descriptive, future studies could investigate relationships between different sub-skills of the LLLTS to identify how one affects the development of the other(s). Students' adaptations of LLL skills as a result of instructional design and/or a change in students' learning contexts could also be investigated. There could also be research into the LLL orientations of learners in different disciplines and types of institution. This would help determine how (in)voluntary participation in learning may affect learners' motivation and therefore LLL orientation.

The nature of language learning as a continuous endeavor suggests that those involved in foreign language teaching and learning need to be active seekers of knowledge. To this end, teachers would benefit from not only staying abreast of the latest research in the field, but also undertaking their own action research. Students can also benefit in terms of motivation and improved language learning if they also conduct research with teacher support. Teachers' and students' experience in seeking greater knowledge through research would help them both become lifelong learners.

\section{References}

Akram, M. \& Ghani, M. (2013). Gender and language learning motivation. Academic Research International, 4(2), 536-540.

Al-Harthi, A.S.A. (2007). Learner self-regulation in distance education: a cross-cultural study. Unpublished doctoral dissertation, the Pennsylvania State University, PA.

Al-Othman, F.H.M. \& Shuqair, K.M. (2013). The impact of motivation on English language learning in the Gulf States. International Journal of Higher Education, 2(4), 123-130.

Al-Tamimi, A. \& Shuib, M. (2009). Motivation and attitudes towards learning English: a study of petroleum engineering undergraduates at Hadhramout University of Sciences and Technology. GEMA Online Journal of Language Studies, 9(2), 29-55.

Arsal, Z. (2011). Lifelong learning tendencies of the prospective teachers in the Bologna process in Turkey. ATTE Annual Conference 2011: Teachers' Life-cycle from Initial Teacher Education to Experienced Professional. Latvia University, Riga 496-509.

Deveci, T. (2015). A comparative study of the lifelong learning propensities of English language learners: nationality, gender and length of study. Learning and Teaching in Higher Education: Gulf Perspectives, 12(1). 
Ayhan, S. (2006). Lifelong learning in the past and today. In F. Sayilan \& A. Yildiz. (Eds). Lifelong learning (pp. 2-23). Ankara: Educational Sciences Institute and Pegem A.

Bahous,R., Bacha, N. N. \& Nabhani, M. (2011). Motivating students in the EFL classroom: a case study of perspectives. English Language Teaching, 4(3), 33-43.

Bandura, A. (1989). Human agency in social cognitive theory. American Psychologist, 44(9), 1175-1184.

Bandura, A. (1991). Self-regulation of motivation through anticipatory and self-reactive mechanisms. In R. Dienstbier (Ed.), Nebraska symposium on motivation, 38, (pp. 69-164). Lincoln: University of Nebraska Press.

Barlas, F. (2012). ELT learners' views on learner autonomy at Balikesir University Necatibey Education Faculty. Unpublished master's thesis, Balikesir University, Balikesir.

Baylan, S. (2007). University students' and their teachers' perceptions and expectations of learner autonomy in EFL prep classes. Unpublished master's thesis, Marmara University, Istanbul.

Bennett, M. J. (1998). Intercultural communication: a current perspective. In M. J. Bennett (Ed.) Basic concepts of intercultural communication. Selected readings (pp. 1-34). Yarmouth, MA: Intercultural Press, Inc.

Bolhuis, S. (2003). Towards process-oriented teaching for self-directed lifelong learning: a multidimensional perspective. Learning and Instruction, 13(3), 327-347.

Bruner, J. S. (1968). Toward a theory of instruction. New York: W.W. Norton \& Company, Inc.

Commission of the European Communities (CEC). (1995). White paper: education and training: teaching and learning: towards the learning society. Luxembourg: Office for Official Publications of the European Communities.

Coskun, Y.D. \& Demirel, M. (2012). Universite ogrencilerinin yasam boyu ogrenme egilimleri [University students' propensities for lifelong learning], Hacettepe Universitesi Egitim Fakultesi Dergisi [Hacettepe University Education Faculty Journal], 42, 108-120.

Deveci, T. (2013). Promoting lifelong learning. Asian EFL Journal Professional Teaching Articles, 72, 4-19. http://asian-efl-journal.com/wp-content/uploads/mgm/downloads/08046800.pdf

Dornyei, Z. (1994). Motivation and motivating in the foreign language classroom. The Modern Language Journal, 78(3), 273-284.

Erten, I. H. (2009). Gender differences in academic achievement among Turkish prospective teachers of English as a foreign language. European Journal of Teacher Education, 2(32), 75-91.

Ervin, S. \& Bower, R. T. (1952). Translation problems in international surveys. Public Opinion Quarterly, 16(4), 595-604.

Garipoglu, B.C. (2013). The effects of self-efficacy on the lifelong learning tendencies of computer education and instructional technologies pre-service teachers: a case study. International Journal of Human Sciences, 10(1), 224-236.

Gunuc, S., Odabasi, H.F. \& Kuzu, A. (2012). Yasam boyu ogrenmeyi etkileyen faktorler [Factors affecting lifelong learning]. Gaziantep Universitesi Sosyal Bilimler Dergisi [Gaziantep University Social Sciences Journal], 11(2), 309-325.

Deveci, T. (2015). A comparative study of the lifelong learning propensities of English language learners: nationality, gender and length of study. Learning and Teaching in Higher Education: Gulf Perspectives, 12(1). 
Hepper, P.G. (1989). Foetal learning: implications for psychiatry?. The British Journal of Psychiatry, 155, 289-293.

Herman, J. L., Aschbacher, P. R. \& Winters, L. (1992). A practical guide to alternative assessment. Alexandria, VA: Association for Supervision and Curriculum Development (ASCD).

Holec, H. (1981). Autonomy and foreign language learning. Oxford: Pergamon Press.

Holt, J. (2001). Motivation as a contributing factor in second language acquisition. The Internet TESL Journal, 7(6), 1-6.

Iqbal, M. J. (2009). Lifelong education: a conceptual debate. International Journal of Media, Technology and Lifelong Learning, 5(1), 1-8.

Javid, Z. C., Al-Asmari, A. R. \& Farooq, U. (2012). Saudi undergraduates' motivational orientations towards English language learning along gender and university major lines: a comparative study. European Journal of Social Sciences, 27(2), 283-300.

Kanik, F. (2002). Evaluation of the effectiveness of the ESP reading materials for 215 English for law course at the English language school of Baskent University. Unpublished master's thesis. Middle East Technical University, Ankara.

Kellaghan, T., Madaus, G. F.,\& Raczak, A. (1996). The use of external examinations to improve student motivation. Washington, DC: American Education Research Association.

Knapper, C., \& Cropley, A. (2000). Lifelong learning in higher education, London: Kogan Page.

Knowles, M. (1975). Self-directed learning. Cambridge: Cambridge Adult Education.

Kocak, A. (2003). A study on learners' readiness for autonomous learning of English as a foreign language. Unpublished master's thesis. Middle East Technical University, Ankara.

Kolata, G. (1984). Studying learning in the womb. Science, 225(4659), 302-303.

Korhonen, V. (2010). Towards intercultural sensitivity: some considerations when studying cross-cultural issues from a lifelong learning perspective, In V. Korhonen (Ed). Cross-cultural lifelong learning (pp. 1536), Tampere: Tampere University Press.

Litman, J. A. (2005). Curiosity and the pleasures of learning: wanting and liking new information. Cognition and Emotion, 19(6), 793-814.

Martens, M. (2013). Plenty of womb to learn. International Journal of Childbirth Education, 28(2), 73-75.

McCombs, B. L. (1991). Motivation and lifelong learning. Educational Psychologist, 26(2), 117-127.

McDonald, J. H. (2009). Handbook of biological statistics. Baltimore: Sparky House Publishing.

Mohammed, E. (2008, May 26). The debate on UAE national identity. Gulf News. Retrieved from http://gulfnews.com/news/gulf/uae/general/the-debate-on-uae-national-identity-1.106921

OECD. (1996). Lifelong learning for all: Meeting of the Education Committee at Ministerial Level, 16-17 January 1996. Paris: OECD.

Ozturk, G. \& Gurbuz, N. (2013). Motivational orientations of Turkish EFL students: the case at a state university. Journal of Language and Literature Education, 8, 62-77.

Deveci, T. (2015). A comparative study of the lifelong learning propensities of English language learners: nationality, gender and length of study. Learning and Teaching in Higher Education: Gulf Perspectives, 12(1). 
Pajares, F. (2002). Overview of social cognitive theory and of self-efficacy. Retrieved January 22, 2014, from http://www.emory.edu/EDUCATION/mfp/eff.html.

Perseverance. (n.d.). In Merriam-Webster's online dictionary. Retrieved February 11, 2014. http://www.merriam-webster.com/dictionary/perseverance

Piccone, J. (1999). Curiosity and exploration. California State University, Northridge. Retrieved April 13, 2014, from http://www.csun.edu/ vcpsy00h/students/curious.htm

Pritchard, R. \& Ashwood, E. (2008). Managing motivation. New York: Taylor \& Francis Group

Rovai, A. P. (2003). In search of higher persistence rates in distance education online programs. Internet and Higher Education, 6, 1-16.

Ryan, R. M. \& Deci, E. L. (2000). Intrinsic and extrinsic motivations: classic definitions and new directions, Contemporary Educational Psychology. 25, 54-67.

Sad, S. N. \& Gurbuzturk, O. (2009). Analyzing the self-determination levels of English prep student by some variables (Inonu University case). Education Administration: Theory and Practice, 15(59), 421-450.

Schmidt, R. Boraie, D. \& Kassabgy, O. (1996). Foreign language motivation: internal structure and external connections. In R. Oxford (Ed.), Language learning motivation: pathways to the new century (pp.9-70). Honolulu, HI: University of Hawai'i, National Foreign Language Resource Center.

Sertcekic, S. P. (2008). Administrative and organizational problems in foreign language education at universities. Unpublished Master's thesis. Yeditepe University, Istanbul.

Silverman, D. (2010). Doing qualitative research. London: Sage

Shoaib, A. \& Dornyei, Z. (2005). Affect in lifelong learning: exploring L2 motivation as a dynamic process. In P. Benson \& D. Nunan (Eds.), Learners' stories: Difference and diversity in language learning (pp. 2241). Cambridge: Cambridge University Press.

Skinner, E. A. (1995). Perceived control, motivation and coping. Sage Series on Individual Differences and Development (Vol. 8). Thousand Oaks, CA, US: Sage Publications.

Suh, E., Diener, E., Oishi S. \& Triandis, H.C. (1998). The shifting basis of life satisfaction judgments across cultures: emotions versus norms. Journal of Personality and Social Psychology, 74, 482-493.

Titmus, C. (1979). Terminology of adult education, UNESCO, Paris: UNESCO.

UNESCO Institute of Education. (2003). Contributing to peace and human development in an era of globalization through education, the sciences, culture and communication, Medium-term Strategy, 20022007 the United Nations Educational, Scientific and Cultural Organization. Retrieved February 17, 2014, from http://unesdoc.unesco.org/images/0012/001254/125434e.pdf

UNESCO Institute for Lifelong Learning. (2009). Building on our gains, medium-term strategy, 2008-2013. Retrieved December 12, 2013, from http://uil.unesco.org/fileadmin/download/en/informationmaterials/Medium-term\%20Strategy\%202008-2013.pdf

Williams, M. \& Burden, R.L. (1997). Psychology for language teachers: a social constructivist approach. Cambridge: Cambridge University Press.

Yalcin, T. F. \& Yalcin, E. (2005). An analysis of the relationship between the use of grammar learning strategies and student achievement at English preparatory classes. Journal of Language and Linguistic Studies, 1(2), 155-169.

Deveci, T. (2015). A comparative study of the lifelong learning propensities of English language learners: nationality, gender and length of study. Learning and Teaching in Higher Education: Gulf Perspectives, 12(1). 
Yurtseven, N., Altun, S. \& Aydin, H. (2013). An analysis on motivational beliefs of preparatory class students about learning English. WULFENIA Journal, 20(5), 155-170.

Deveci, T. (2015). A comparative study of the lifelong learning propensities of English language learners: nationality, gender and length of study. Learning and Teaching in Higher Education: Gulf Perspectives, 12(1). 


\section{Appendix}

\section{Questionnaire used in this study}

This questionnaire aims to determine the level of lifelong learning tendencies of the students learning English as a foreign language. Please give sincere responses.

\section{Part A}

1. What is your gender?

Female Male

2. What is your nationality?

3. How long have you been learning English at your current school.
a) less than 6 months
b) between 6 and 12 months
c) more than 12 months

\section{Part B}

Please indicate how much you agree or disagree with the statements below. Use the scale below.

\begin{tabular}{|l|l|l|l|l|l|}
\hline 6 & 5 & 4 & 3 & 2 & 1 \\
\hline Strongly agree & Agree & $\begin{array}{l}\text { Somewhat } \\
\text { agree }\end{array}$ & $\begin{array}{l}\text { Somewhat } \\
\text { disagree }\end{array}$ & Disagree & Strongly disagree \\
\hline
\end{tabular}

\begin{tabular}{|c|c|c|c|c|c|c|}
\hline & 6 & 5 & 4 & 3 & 2 & 1 \\
\hline $\begin{array}{l}\text { 1. I love to learn English as well as new knowledge and skills in different } \\
\text { areas that would contribute to my personal development. }\end{array}$ & & & & & & \\
\hline $\begin{array}{l}\text { 2. I can learn any kind of knowledge if I believe it will contribute to my } \\
\text { personal development. }\end{array}$ & & & & & & \\
\hline $\begin{array}{l}\text { 3. One of my priorities in life is to achieve personal development by } \\
\text { improving my English and continuously learning new things and skills. }\end{array}$ & & & & & & \\
\hline $\begin{array}{l}\text { 4. I would continue learning English, new knowledge and skills for } \\
\text { personal development even if I were financially secure. }\end{array}$ & & & & & & \\
\hline 5. Learning new things all the time is a passion for me. & & & & & & \\
\hline $\begin{array}{l}\text { 6. I am more willing to learn English, new knowledge and skills than my } \\
\text { friends. }\end{array}$ & & & & & & \\
\hline
\end{tabular}

Deveci, T. (2015). A comparative study of the lifelong learning propensities of English language learners: nationality, gender and length of study. Learning and Teaching in Higher Education: Gulf Perspectives, 12(1). 


\begin{tabular}{|c|c|c|c|c|c|c|}
\hline & 6 & 5 & 4 & 3 & 2 & 1 \\
\hline \multicolumn{7}{|l|}{$\begin{array}{l}\text { 7. I like to spend most of my time doing research in order to improve } \\
\text { my English and learn new things. }\end{array}$} \\
\hline \multicolumn{7}{|l|}{$\begin{array}{l}\text { 8. I create opportunities to improve my English and learn new } \\
\text { knowledge and skills on my own even if my schedule is tight. }\end{array}$} \\
\hline \multicolumn{7}{|l|}{$\begin{array}{l}\text { 9. I allocate a certain amount of my budget to improve my English and } \\
\text { learn new knowledge and skills. }\end{array}$} \\
\hline \multicolumn{7}{|l|}{$\begin{array}{l}\text { 10. I try to improve my English and learn new knowledge and skills } \\
\text { without any pressure from others. }\end{array}$} \\
\hline \multicolumn{7}{|l|}{$\begin{array}{l}\text { 11. In the process of learning English, I also try to learn new knowledge } \\
\text { and skills that may not necessarily be related to English language. }\end{array}$} \\
\hline \multicolumn{7}{|l|}{$\begin{array}{l}\text { 12. Even if what I am trying to learn is difficult and confusing, I do my } \\
\text { best to learn it. }\end{array}$} \\
\hline & 6 & 5 & 4 & 3 & 2 & 1 \\
\hline \multicolumn{7}{|l|}{$\begin{array}{l}\text { 13. Learning new knowledge and skills unrelated to my English classes } \\
\text { is not useful. }\end{array}$} \\
\hline \multicolumn{7}{|l|}{$\begin{array}{l}\text { 14. It is meaningless to continuously learn new knowledge and skills for } \\
\text { personal development. }\end{array}$} \\
\hline \multicolumn{7}{|l|}{$\begin{array}{l}\text { 15. I do not find the contributions of those around me relevant to my } \\
\text { learning process. }\end{array}$} \\
\hline \multicolumn{7}{|l|}{$\begin{array}{l}\text { 16. I do not refer to variety of sources of information related to English } \\
\text { such as supplementary books and the internet if I don't have to. }\end{array}$} \\
\hline \multicolumn{7}{|l|}{$\begin{array}{l}\text { 17. I would have difficulty in improving my English and learning new } \\
\text { knowledge and skills after graduation. }\end{array}$} \\
\hline $\begin{array}{l}\text { 18. I find it stressful to evaluate my own learning and this makes } \\
\text { learning new things difficult for me. }\end{array}$ & & & & & & \\
\hline
\end{tabular}

\begin{tabular}{|l|l|l|l|l|l|}
\hline \multicolumn{1}{|l|}{$\begin{array}{l}\text { 19. I do not like to spend my time doing research unless I have to } \\
\text { because of a project, an exam etc. }\end{array}$} & & & & & \\
\hline $\begin{array}{l}\text { 20. I prefer to spend my time with my loved ones instead of spending } \\
\text { it for my personal development. }\end{array}$ & & & & & \\
\hline $\begin{array}{l}\text { 21. I do not find it necessary to make up for lack of knowledge unless I } \\
\text { have to do so because of an exam etc. }\end{array}$ & & & & & \\
\hline
\end{tabular}

Deveci, T. (2015). A comparative study of the lifelong learning propensities of English language learners: nationality, gender and length of study. Learning and Teaching in Higher Education: Gulf Perspectives, 12(1). 


\begin{tabular}{|l|l|l|l|l|}
\hline $\begin{array}{l}\text { 22. I think it is a waste of time to go to extra-curricular activities such } \\
\text { as seminars and tutorials to improve my English and learn new } \\
\text { things, unless / have to. }\end{array}$ & & & & \\
\hline $\begin{array}{l}\text { 23. I do not spend time learning about something just because I am } \\
\text { curious about it. }\end{array}$ & & & & \\
\hline $\begin{array}{l}\text { 24. Libraries are boring places. } \\
\text { 25. I prefer spending time for my hobbies instead of learning new } \\
\text { things unless / have to. }\end{array}$ & & & & \\
\hline $\begin{array}{l}\text { 26. I do not want to learn new knowledge and skills if it causes me } \\
\text { financial problems. }\end{array}$ & & & & \\
\hline $\begin{array}{l}\text { 27. Continuously having to learn new knowledge and skills is a } \\
\text { burden on me. }\end{array}$ & & & & \\
\hline
\end{tabular}

\section{Part C}

This section is optional. However, your responses to the questions below would be appreciated.

Please elaborate on your answers.

1) What makes you curious about learning English?

2) Do you ever decide to learn what you want to learn? Why (not)?

3) Do you ever revise your priorities in terms of language learning? Why (not)?

4) Do you ever lose your motivation to learn English? Why (not)?

5) What keeps you interested in learning English?

6) What do you do when you face difficulties in learning English?

Deveci, T. (2015). A comparative study of the lifelong learning propensities of English language learners: nationality, gender and length of study. Learning and Teaching in Higher Education: Gulf Perspectives, 12(1). 
Deveci, T. (2015). A comparative study of the lifelong learning propensities of English language learners: nationality, gender and length of study. Learning and Teaching in Higher Education: Gulf Perspectives, 12(1). http://lthe.zu.ac.ae 